Man and Nature

L'homme et la nature

\title{
Revolution, Reaction, and the Expropriation of Popular Culture: Hannah More's Cheap Repository
}

\section{Gary Kelly}

Volume 6, 1987

URI : https://id.erudit.org/iderudit/1011875ar

DOI : https://doi.org/10.7202/1011875ar

Aller au sommaire du numéro

Éditeur(s)

Canadian Society for Eighteenth-Century Studies / Société canadienne d'étude du dix-huitième siècle

ISSN

0824-3298 (imprimé)

1927-8810 (numérique)

Découvrir la revue

Citer cet article

Kelly, G. (1987). Revolution, Reaction, and the Expropriation of Popular Culture: Hannah More's Cheap Repository. Man and Nature / L'homme et la nature, 6, 147-159. https://doi.org/10.7202/1011875ar

Copyright (c) Canadian Society for Eighteenth-Century Studies / Sociéte canadienne d'étude du dix-huitième siècle, 1987
Ce document est protégé par la loi sur le droit d'auteur. L'utilisation des services d'Érudit (y compris la reproduction) est assujettie à sa politique d'utilisation que vous pouvez consulter en ligne.

https://apropos.erudit.org/fr/usagers/politique-dutilisation/ 


\section{REVOLUTION, REACTION, AND THE EXPROPRIATION OF POPULAR CULTURE: HANNAH MORE'S CHEAP REPOSITORY}

In March 1790 Hannah More, author, retired schoolmistress, Evangelical, and leader of the Sunday school movement, wrote to her sister:

Things are getting worse and worse in France. A lady of quality the other day in Paris, rung her bell, and desired the footman to send up her maid Jeannotte. In vain she rung and rung; the man told her, Jeannotte refused to come; or be any longer under any body. At last Jeannotte walked into the room with a pamphlet open in her hand, and sat down. The lady astonished, asked her what she meant. "C'est que je lise," said Jeannotte, without taking her eyes off the book. The lady insisted on an explanation of this impertinence. The maid replied with great sang froid, "Madame, c'est que nous allons tous devenir egaux, et je me prepare pour l'egalité."1

More's dismay at this example of impertinent reading was a paradox. She was a leader in bringing literacy to Jeannotte's English counterparts through Sunday schools, and she believed that literacy, in itself, would help to support social order and a proper subordination of rank. Only a year before, she had written to the great Evangelical 
gentleman and Parliamentarian, William Wilberforce, of her success in persuading the gentry in Cheddar, Somerset, to support her Sunday schools:

I was told we should meet with great opposition if I did not try to propitiate the chief despot of the village [i.e., the local 'squire], who is very rich, and very brutal. ... He begged I would not think of bringing any religion into the country; it was the worst thing in the world for the poor, for it made them lazy and useless. In vain did I represent to him that they would be more industrious as they were better principled ... I found that friends must be secured at all events, for if these rich savages set their faces against us, and influenced the poor people, I saw that nothing but hostilities would ensue; so I made eleven more of these agreeable visits ... I ... said that I had a little plan which I hoped would secure their orchards from being robbed, their rabbits from being shot, their game from being stolen, and which might lower the poor-rates. If effect be the best proof of eloquence, then mine was a good speech, for I gained at length the hearty concurrence of the whole people, and their promise to discourage or favour the poor in proportion as they were attentive or negligent in sending their children. ${ }^{2}$

Well might More boast of her political skills to Wilberforce. She saw that to get at the poor she had to use their masters; she knew the realities of control and supervision in rural society; she believed literacy would work moral and social reform; and she was determined to use the social realities for those ends, her own ends.

In the early 1790s, however, she realized that literacy could be used for other ends as well. The growth of artisan political movements, with their own publications, often written in vulgar racy idiom, along with the sale of hundreds of thousands of copies of Tom Paine's Rights of Man, political songs, allegories, and narratives, made the leaders of the campaign for literacy for the poor produce pseudo-popular print of their own, for their own purposes. As More's biographer put it, "To teach the poor to read, she now saw, was putting a dangerous engine into their hands, unless safe and salutary reading was also provided." "As the school of Paine had been labouring to undermine, not only religious establishments, but good government, by the alluring vehicles of novels, stories [i.e., short fictions in chapbook form], and songs [i.e., broadsheets], she thought it right to encounter them with their own weapons ..." ${ }^{\prime 3}$ In order to prepare herself for producing "safe and salutary reading," More collected a wide range of the "street literature," the popular broadsheets and chapbooks of the day--what she referrred to as her "sans-culotte library." 
This library has been lost, but it is easy to reconstruct. ${ }^{4}$ Apart from the political song-sheets, it would include little that was overtly political. It would include many chapbooks first published over a century or two earlier, such as Valentine and Orson, Guy of Warwick, Jack and the Giants, Tom Hickathrift, Dick Whittington, The Fair Rosamond, Robin Hood, jest books, fortune-telling books, folk-medicine books, and "garlands" of songs. It would include some material of more recent date, such as books of travels both factual and fabulous (for example, Capt. Cook for fact and Baron Munchausen for the fabulous), tales plagiarized from late eighteenth-century miscellany magazines, cut-down novels, narrative versions of plays, and such stories as the Life of Bampfylde Moore Carew, King of the Gypsies. However, even the more recent recruits tended, as yet (this would change after 1800), to be assimilated to the patterns and the values found in the traditional popular prints. These patterns and values were, as far as we can tell, close in many ways to those found in the narratives and songs of traditional oral culture. ${ }^{5}$ Such oral and printed texts recognize social inequality and injustice, acknowledge the hegemony of the gentry, protest mildly and obliquely against abuses of paternalism, and see human life as part of an unchanging but often capricious cosmic order, which humans can do little to alter or direct. It is a world-view of fatalistic protest, but one that recurs again and again to the possibility that "natural" if limited human attributes such as great strength, cleverness, or beauty can bring about some improvement in the individual life. On the one hand fatalism; on the other a lottery mentality.

Jack the Giant-Killer, for example, is the son of a farmer, thus not "gently-born," but is gifted with great strength and cleverness, and so outwits not only giants but also the local clergyman, cracks crude jests against both, and after rescuing a variety of gentlefolk is rewarded with an estate and a genteel wife. Fair Rosamond is gently born, but loved by one--a king--above her sphere. She, too, enjoys social elevation and power, at the price of her "virtue," but then she falls through the court intrigues of her enemies, who consider themselves her "betters." Valentine and Orson (the story goes back to a medieval French verse romance $)^{6}$ are gently born, but raised apart. Orson's true identity is concealed and he lives as a wild man of the woods until his brother overpowers him, cuts a thread binding his tongue, and thus frees him into speech and his rightful social rank. The brothers overcome an exotic world of pagans and sorcerers, gain wealth, fame, and women, but die as all men must--their glory amounts to little in the face of mortality. The Robin Hood stories feature the same combination of colloquial wittiness, displays of physical strength and dexterity, social protest 
against tyrants, and restoration of a just though still hierarchical and paternalistic society found in Jack and the Giants. Dick Whittington is a kind of Jack the Giant-Killer for lonely town apprentices. The popular criminal biographies, of the type developed at length by Defoe, as well as the travel narratives, also exhibit dexterity, cleverness, and a sense of fatalism--the crowning example, perhaps, is that great eighteenth-century popular classic, Robinson Crusoe. In all these tales providential gifts of strength, ingenuity, and beauty are set against a sense of human destiny beyond individual control. Furthermore, the traditional chapbooks as well as the more recent recruits register an awareness of social injustice and inequality, plot fantasies of individual triumph over such circumstances, yet reveal a fatalistic acceptance of the rarity or the fleetingness of such triumph. In other words, the traditional chapbooks accept gentry hegemony without embracing it, and protest explicitly only against abuses of the paternalistic order.

The world-view presented in this popular literature is very close to what E.P. Thompson has described as "the moral economy of the common people," a moral economy that accepted rural paternalism and protested actively and forcefully only when that paternalism was seen to have become excessively exploitative. ${ }^{7}$ Thompson's "moral economy" is a communal political culture. At the same time, the popular literature represented the individual situation of the artisan or workingclass reader in the situation of those isolated yet self- sufficient heroes of the most popular tales--Crusoe, Jack, Whittington, Orson, even Bunyan's Pilgrim. However, in the 1790s the political movements of the urban artisan and labouring classes began to transform the traditional "moral economy" just as the changing urban popular culture was beginning to transform the traditional repertory of "street literature." The idiom of the popular political pamphleteers such as Tom Paine and Daniel Isaac Eaton borrowed from the language and style of the chapbook heroes, just as the artisan political movements rationalized, historicized, and radicalized the politics of the traditional "moral economy." Professional middle-class social criticism of court culture, court politics, and gentry hegemony, indebted to the European Enlightenments, was quarried by the descendents of Jack the Giant-Killer and Robin Hood. For the majority of lower-class autobiographies of this period describe the same career: early and accidental acquisition of literacy; early acquaintance and infatuation with chapbooks, Robinson Crusoe, and The Pilgrim's Progress; later turning to Methodism, New Dissent, and/or political radicalism; finally, assimilation to the lower levels of the professional world of writing, through the ministry, full-time political work, teaching, or journalism. No wonder Hannah More referred 
to "street literature" as a "sans-culotte library"; no wonder she wanted to seize control of lower-class literacy and reading matter. For liberal Dissenters and professional middle-class men of the Enlightenment were joining with the literate artisan classes in political protest, in such organizations as the London Corresponding Society, and when this happened then the already well-established professional middle-class project of criticizing court culture and gentry hegemony was in danger of being hijacked.

Hannah More and her fellow Anglican Evangelicals were also leaders of professional middle-class culture and ideological expression, and they were determined to direct the movement to subvert gentry hegemony and professionalize society themselves. Thus they had to break up the nascent coalition of artisans, Dissenters, and middle-class professionals in the early 1790s. They had to detach the middle classes from their cultural emulation of and ideological dependence on the gentry. At the same time, they had to break up the traditional "moral economy" of interdependence of rural labouring classes and landed gentry, and make the labouring classes over into lesser versions of the Evangelicals themselves. While More's friends, such as Wilberforce and Bishop Porteous, led in the use of Evangelical religion to professionalize the gentry and clergy, More herself turned in the early 1790s to expropriation of the "moral economy" of the common people. Significantly, she chose to do this by supplanting the print version of this popular culture, the centuries-old "street literature" of chapbooks and broadsheets; for not only was her programme of pseudo-popular print for the people to replace the traditional print repertory, it was to supplant the orality and face-to-face communality of popular culture as well. Print, the cultural province of middle-class professionals, was to remake society in their image.

More's first essay in pseudo-popular print, Village Politics (1792), attacked "Jacobinism" directly, but it was just the harbinger of her grand project, the Cheap Repository, initiated in $1795 .{ }^{8}$ Here she (and her assistants, principally her sister) set about attacking not just the shoots of "Jacobinism," but the roots of popular culture. Cheap Repository's pseudo-popular chapbooks consistently argue that the poverty and misery of the labouring poor are caused not by "things as they are" but by their own idleness, folly, bad management, and mistaken attempts to emulate their betters--their attitude of carpe diem, their interest in luck and fortune-telling, their fatalism and improvidence, their toleration of petty crime on grounds of need, their habits of deceiving their masters, and their imitation of the upper-class amorous culture of gallantry, seduction, and betrayal. Even the popular "moral economy" 
of food, of the right to poach and steal from the gentry, and the right to such occasional "luxuries" as tea, sugar, and meat is attacked in favour of a diminished version of middle-class housekeeping, selfdenial, planning ahead, and the virtues of the potato and cooking with leftovers. More largely, in place of popular fatalism there is shown to be a strict dispensation of justice according to spiritual merit, inspired by divine Providence and operated by God's ministers on earth, the local Evangelicals, and especially the local Evangelical clergyman. For in most Cheap Repository tales the real leader in rural society, the 'squire, is missing altogether. The ideal society of Cheap Repository is presided over by a professionalized clergyman who enjoys divine and transcendental, yet inward validation, thanks to his own personal moment of conversion. Evangelical conversion justifies faith and works, spiritual and temporal authority in the reconstruction of English society. The converted poor, in their smaller way, are often the agents of conversion, too, in home and neighbourhood. Merely political and social reform of the kinds proposed by the English Jacobins are not so much countered as by-passed. Cheap Repository attacks the root rather than what More considered to be the branch.

The formal structure of Cheap Repository tales is a development of that of the traditional and genuinely popular "godly books," but redesigned to embody the Evangelicals' particular vision of society and the individual. In the first place, there is, as one might expect, a thirdperson narrator, omniscient and very authoritative, given to delivering plenty of moral, didactic, and practical asides. Otherwise, the forwarding of themes is managed through dialogues, an ancient device in didactic writing. But in Cheap Repository's dialogues one side is always already right, and so they resemble catechism, revival of which, by the way, was an important element in the Evangelicals' literarytheological culture. Catechism is pseudo-talk, determined by a pretext, requiring internalization of the word by memory, orality already expropriated by writing.

Characterization in Cheap Repository also expropriates both orality and formal elements of popular chapbook fiction. The characters in Cheap Repository tales are simple, as in popular chapbooks, with no interior life, but they are usually given Character or humour names, such as Farmer Bragwell and Farmer Worthy in The Two Wealthy Farmers. Character is reduced to name. Other methods of characterization are the authoritative character sketch and crude use of dialect or sociolect. These techniques are linked. Needless to say, the authoritative characters and especially the clergymen speak in standard written English. Those with the most "deviant" speech are often the unredeem- 
able low-lifes, while the converted or convertible poor not only speak more "correctly," what they speak is the Word. Quotations from the Bible, hymns, Book of Common Prayer, and other classics of the Evangelical culture of writing, and of which the Evangelical clergyman is the authoritative dispenser, have been internalized by the converted poor so that they have become simply repositories of the Evangelicals' word--the more happily so when they are beneficiaries of Evangelical Sunday school literacy, too. As in the popular chapbooks, then, the common people have no inwardness to speak of, little of that private selfhood so rapidly developing in the hands of Romantic and RomanticEvangelical writers. In the Cheap Repository tales the clergyman and the middle-class Evangelical folk have inwardness as reflectiveness, self-discipline, foresight, and the Word; the common folk internalize the Word, and then follow and imitate the inwardness of their "betters." They have little of their own otherwise, apart from anticipation of the reward for the poor hereafter. Thus the corrupt communalities of the oral culture and the popular "moral economy"--caricatures of decadent court and gentry culture--are reflected in the unredeemable characters' dialect and sociolect, their orientation to popular speech; the virtues of the new, transcendent community of Evangelicalism are reflected in the orientation of shepherd and flock to the Word, the specifically Evangelical culture of writing. Such distribution of language, inwardness, and value along lines of class would be made even more obvious in the chapbooks of More's Evangelical heirs, writers such as the Rev. Legh Richmond (Annals of the Poor, 1809-12) and Mrs. Sherwood (Little Henry and His Bearer, 1814). More obviously, such distribution was to be institutionalized in the social-historical novels of the 1810 s and 1820s and in Victorian secular high culture. The pattern is, I think, with us even now.

The authoritative narrative voice, tendentious description, and unequal linguistic universe are supported by the plots of the Cheap Repository tales, although the structural co-ordination of a particular distribution of language, selfhood, and authority is the real point of More's project. Plotting that distribution, casting the structure as a narrative line, was a burden to More, her helpers and successors. Perhaps she saw a close relationship between orality and narrativity; certainly the genuinely popular chapbooks are full of incident and action, though their plots are loose and desultory, often mere collections of anecdotes, with little progression or closure. Such plots exhibit the chanciness of life, the lottery of existence. Cheap Repository tales, by contrast, plot a strict apportionment of rewards and punishments. Popular tales often dwell on trials and tribulations; so do Cheap Repository tales, but with 
a different emphasis and upshot. The converted poor, often doubly reduced from social importance as youths or old people, are nevertheless made the repositories of the highest truths and therefore have to face the envy, hostility, and persecution of their unconverted social peers. But the descent of a spiritual peer and social superior, a deus ex machina, in the guise of the Evangelical validator and helper, brings about a reversal of worldly and social injustice. However, any significant social rise as the reward of spiritual emulation is carefully avoided as a conclusion to the plot--not for Cheap Repository tales the upshot of Jack and the Giants or Dick Whittington or even Robinson Crusoe. And for Cheap Repository certainly not the kind of merely circumstantial or coincidental punishments found in Fair Rosamond, Valentine and Orson, or such popular genres as the criminal biography and the shipwreck narrative. Indeed, one of the favourite closures of More's successors is the deathbed, the transition from this world (no reward) to the next (the only real reward).

How successful was More's expropriation of popular culture? This is difficult to estimate, but a few facts are highly suggestive. Very soon after they began to appear, the Cheap Repository tracts were demanded in editions on "superior" paper and with finer printing, suitable for binding for the libraries of the middle and upper ranks in society. Significant, too, is the fact that More and her supporters realized the distribution of Cheap Repository would have to be forced, that is, chapmen and booksellers would have to be bribed or menaced into selling these wares alongside or in place of their usual stock. Most revealing of all, however, is the legend that appears in some form or other on the cover of almost all the Cheap Repository tracts: "Price One Penny, Or 4s. 6d. 100.-2s 6d. for 50.-1s. 6d. for 25."9 The tracts were to be sold in bulk, to the gentry and middle classes, and distributed free to the labouring classes. This practice had been developed earlier, of course, but Cheap Repository made it systematic and on a grand scale, with a programme of monthly publication of "Histories," "Sunday Readings," and "Poetry." More important, the pricing policy and the calls for "superior" editions strongly suggest that the tracts appealed more to the middle and upper ranks, because they represented their class-based view of the lower ranks. The unconverted and unconvertible poor are shown to be responsible for their own plight yet relatively harmless, like naughty children; the converted poor are shown to be diminished and docile versions of the fully human middle-class Evangelicals who, in their turn, are divinely legitimized social leaders, teachers, counsellors. Not only did the Cheap Repository tracts set out to expropriate popular culture; they represented a vision, a fan- 
tasy of social order inspired, reconstructed, and presided over by the Evangelicals themselves. The vision was sharpened and given much wider circulation by the Religious Tract Society, founded in 1799 . The R.T.S. carried More's project far beyond its original intention to supplant and subvert the "sans-culotte library" of popular culture, and to end the kind of impertinent reading that shocked More in the anecdote of the Parisian lady and her Jeannotte. But the R.T.S.'s work, along with the novelistic appropriation of popular culture conducted by Walter Scott and his followers, took More's politics of language to every level of Victorian intellectual and artistic culture. That, however, is another story.

\section{G. KELLY}

University of Alberta

\section{NOTES}

1. William Roberts, Memoirs of the Life of Mrs. Hannah More, 2 vols. (London: R. B. Seeley and W. Burnside, 1836), I. 463.

2. Ibid., I. 449-51.

3. Ibid., I. 552, 553.

4. I base this reconstruction on surveys of collections in the British Library, the Bodleian Library, and the Bride Lane Printing History Library (London), and on a survey of several score early nineteenth-century working-class autobiographies, including those of John Clare, Samuel Bamford, and George Miller. See also David Vincent, Bread, Knowledge and Freedom. A Study of NineteenthCentury Working Class Autobiography (London: Europa Publications, 1981).

5. See Robert Muchembled, Culture populaire et culture des élites dans la France moderne (Paris: Flammarion, 1978); Margaret Spufford, Small Books and Pleasant Histories. Popular Fiction and Its Readership in Seventeenth-Century England (London: Methuen, 1981); Peter Burke, Popular Culture in Early Modern Europe (London: Temple Smith, 1978); Victor E. Neuburg, Popular Literature. A History and Guide (Harmondsworth: Penguin Books, 1977); Robert Mandrou, De la culture populaire aux XVIIe et XVIIIe siècles (Paris: Stock, 1964, 1975).

6. See Arthur Dickson, Valentine and Orson (New York, 1929).

7. Edward P. Thompson, "The Moral Economy of the English Crowd in the Eighteenth Century," Past and Present, 50 (Feb. 1971), 76-136.

8. See G. H. Spinney, "Cheap Repository Tracts: Hazard and Marshall Edition," The Library, fourth series, 20 (1939).

9. Title page to The Sunday School. 
Merry Frolicks,

O R T H E

COMICAI CHEATS

O F

$S W A L P O$

A Notorious Pick-Pocket,

And the Merry. Pranks of

ROGER the CLOWN:

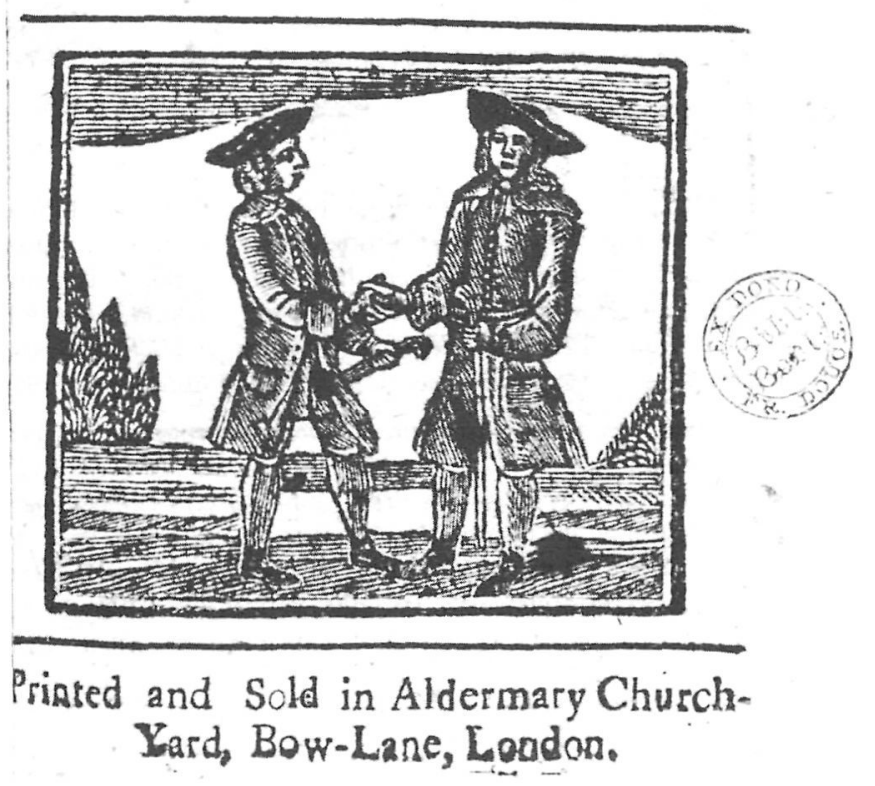

Swalpo: A typical eighteenth-century chapbook, in the design format imitated by Cheap Repository. 


\section{CHEAP REPOSITORY.}

\section{T H E \\ Shepherd of Salifbury-Plain.}

\section{P A R T I.}

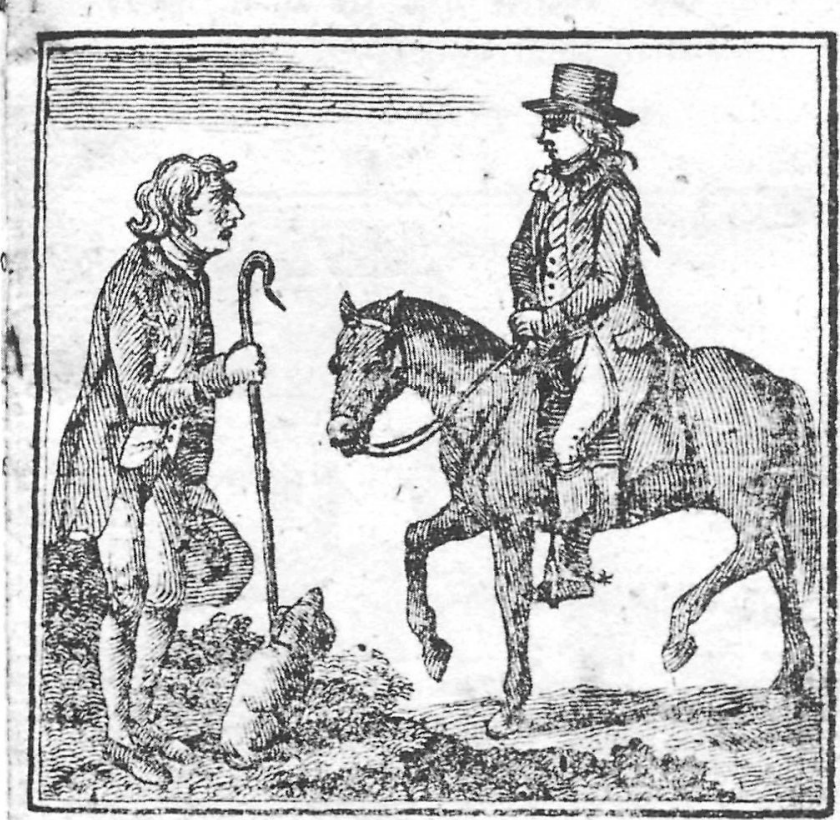

Sold by J.MARSHALL

UPRINTEP to the CHEAP REPCSITORY for MOra! and Regigious Tracts) No. 17, Queen Street Cheapfide, and No. 4, Aldermary Church-Yard and $k$. WHITE, Piccadilly, LONDON.

By s.HAZARD, at BATH: and by all Bookfellers, New imen, and Hawkers, in Town and Country. Great Allowance will be made to Shopkeepers and Hawkers.

$$
\text { PRICE ONE HALFPENNY. }
$$

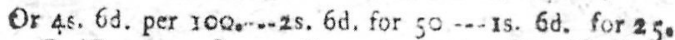

$$
\text { [Entered at Stationers Hall. ] }
$$

The Shepherd of Salisbury Plain: One of the best-known early Cheap Repository tracts, setting forth the moral and social reform effected by the Evangelical on horseback. 


\section{Q.7. CHEAP REPOSITOR.Y. \\ BLACK GILES the Poacher;}

W, ith fome Account of a

Family who had rather live by their Wits than their Work.

P A R T I.

T.

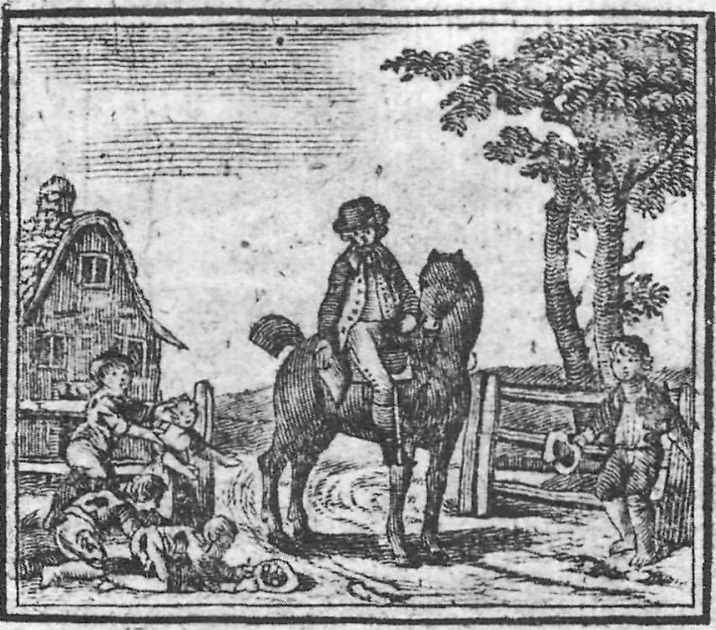

Sold by J. MARSHALL,

(PBINTER tethe Cheap REPository for Moral and Religious Tracts) No. 17 , Queen-Street, Cheapfide, and No. 4, Aldermary Church-Yard, and R. WHITE, Piccadilly, London.

By S. HAZARD, at Bath: and by all Bookfellers, Newl- men, and Hawkers in Town and Country.

Great Allowance rwill be made to Shopkecpers and Ha wokers. PRICE ONE PENNY:

[Entered at Stationers Hall. ]

Black Giles and Tawny Rachel: Two Cheap Repository tracts attacking traditional popular culture, the main concern of Cheap Repository tales, rather than popular 'Jacobinism' or political protest.

Copyright Bodleian Library 


\section{This is the $3^{\text {d hart of }}$ B Lack Gile.} CHEAP REPOSITORY

\section{TAWNY RACHEL, \\ (1) $\mathrm{B}_{9}$}

The FORTUNE TELLER;

With fome Account of Dreams, Omens and Conjurer.

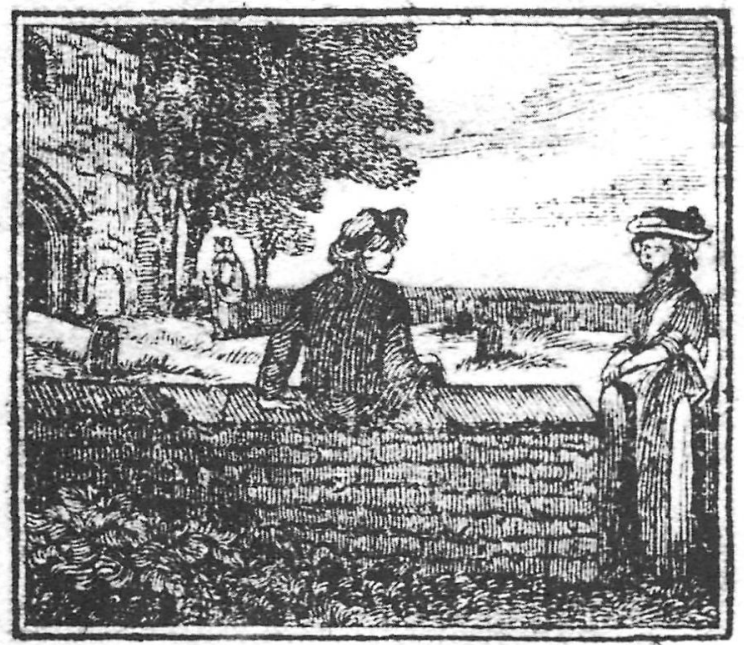

Sold by J: MARSHALL,

(PRINTER to the CheAp Repository for Moral and Re ligious Trąts) No. I7, Queen-Street, Cheapfide, and No. 4, Aldermary Church-Yard, and R. WHITE, Pis. cadilly, London.

By S. HAZARD, at Bath; J. Elder, at Edin'urgh, and by all Bookfellers, Newfmen, and Hawhers, in Town and Country.

Gre at Allowance will be made to Shopkeepers aud Hawkers: PRICE ONE PENNY.

[Entered at Stationers Hall.] 